\title{
Cezayir'de Yabancı Dil Olarak Türkçe Öğretimi Üzerine Bir Değerlendirme
}

\author{
Önder Çangal ${ }^{*}$ \\ Makale Geliş Tarihi: 30/12/2020 \\ Makale Kabul Tarihi: 16/01/2021 \\ DOI: $10.35675 /$ befdergi. 850772
}

$\ddot{O} z$

Türkiye-Cezayir ilişkilerinin temeli 16. yüzyıla kadar uzanmakta, Cezayir halkının Osmanlıdan günümüze Türkiye'ye ve Türk halkına duyduğu yakınlı hâlâ geçerliliğini korumaktadır. Son yıllarda artarak devam eden iş birliği çalışmalarının da etkisiyle her yıl yüz binlerce Cezayirli, turist olarak Türkiye'ye gelmekte, farkll sektörlerden Türk firmaları Cezayir'e yatırım yapmaktadır. Gelişstirilen ikili ilişkiler ve ülkede yakından takip edilen Türk dizileri, Türkçe ögrenmeye karşı talebi de artırmakta, mevcut talebin karşılanması için çeşitli kurum ve kuruluşlar faaliyet göstermektedir. Nitel araştırma desenlerinden durum çalışması kullanılarak hazırlanan araştırmada Cezayir'de yabancı dil olarak Türkçe öğretimine ilişkin genel durumun ortaya konulması ve değerlendirmelerde bulunulması amaçlanmıştır. Ülkede yürütülen yabancı dil olarak Türkçe ögrretimi faaliyetlerinin tespit edilmesinin sonraki süreçte gerçekleştirilecek çallşmalar için yol gösterici olacağı düşünülmektedir.

Anahtar Kelimeler: Cezayir, Türkoloji, yabancı dil olarak Türkçe öğretimi

\section{An Evaluation on Teaching Turkish as a Foreign Language in Algeria}

\begin{abstract}
The basis of Turkey-Algeria relations goes back to the 16th century and the people in Algeria have felt close to Turkish people from the Ottomans to Turkey. Every year thousands of Algerian people come to Turkey as tourists and Turkish companies from different sectors also invest in Algeria thanks to the recent cooperation studies. Developing relations and Turkish TV series, which are closely followed in Algeria, increase the demand for learning Turkish in Algeria, and various institutions and organizations operate to meet the current demand. In the research prepared by using case study, one of the qualitative research designs, it is aimed to reveal and evaluate the general situation of teaching Turkish as a foreign language in Algeria. It is thought that determining the activities of teaching Turkish as a foreign language carried out in Algeria will be a guide for future studies.
\end{abstract}

Keywords: Algeria, teaching Turkish as a foreign language, Turcology

\section{Giriş}

Cezayir, Akdeniz kıyılarından Büyük Sahra’nın güney kesimlerine kadar uzanan topraklarıyla Afrika kıtasının alan bakımından Sudan'dan sonra ikinci büyük ülkesidir. Kuzeyde Akdeniz, doğuda Tunus ve Libya, batıda Fas ve Batı Sahra, güneydoğuda Nijer, güneybatıda Mali ve Moritanya ile çevrili olan Cezayir'in yüzölçümü 2.381.741 kilometrekaredir. Cezayir Afrika Birliği, Arap Birliği, Gaziantep Üniversitesi, Gaziantep, Türkiye, ondercangal@ hotmail.com, ORCID: 0000-0002-8560-3526 iD

Kaynak Gösterme: Çangal, Ö. (2021). Cezayir'de Yabancı dil olarak Türkçe öğretimi üzerine bir değerlendirme. Bayburt Ĕgitim Fakültesi Dergisi, 16(Özel Say1), 210-227. https://doi.org/10.35675/befdergi.850772 
Bağlantısız Ülkeler, İslâm Konferansı ve Petrol İhraç Eden Ülkeler teşkilâtlarının üyesidir. Ülkede otuz bir şehir ve iki yüze yakın ilçe bulunmaktadır. Ülkenin başkenti Akdeniz kıyılarında kurulmuş olan "Cezayir” şehridir (Erinç, 1993, s. 483484).

Cezayir tarihi incelendiğinde bölgede ilk olarak göçebe hayatı benimseyen ve "Emazi ̌̆" adı verilen yerli halkın yaşadığı görülmektedir. Ülkede daha sonra Fenikeliler, Romalılar, Bizanslılar ve Vandallar hüküm sürmüş; yedinci yüzyılın ortalarında Müslüman Arapların bölgeye gelmesi ile "Berberi" olarak da anılan yerliler arasında Müslümanlık yayılmıştır. Müslüman Araplar ile Bedevi kabileler arasında 14. yüzyılda çıkan sorunlardan yararlanan İspanyollar ülkenin sahil şeridinde bulunan yerleşimleri ele geçirmeye başlamıştır.

Cerbe Adasına yerleşen ve Yavuz Sultan Selim'in himayesi altına giren Oruç ve Hızır Reis, Cezayir'den gelen bir heyetin İspanyollara karşı kendilerinden yardım istemesi üzerine 1516'da önce Cezayir şehrini sonrasında da Cezayir'in batısındaki Şerşel'i ele geçirmiştir. Bu fetihten sonra Şerşel ve Cezayir Sultanı ilân edilen Oruç Reis iki yıl sonra ele geçirdiği Tilimsân şehrini geri almak isteyen İspanyollara karşı savaşırken şehit olmuş, yerine geçen Hızır Reis 1519'da Yavuz Sultan Selim'den destek istemiştir. Yavuz Sultan Selim, Hızır Reisi Cezayir hâkimi ilan ederek yeniçeri ve topçulardan oluşan 2000 kişilik yardımcı birliği, savaş ve gemi malzemeleri ile birlikte Cezayir'e göndermiştir (Kahraman, 1993, s. 486).

Osmanlının bölgede hâkimiyet kurması sayesinde "Cezayir kentindeki İspanyol işgali 1516 yılında son bulmuştur. Ancak İspanyolların batıda yer alan Oran şehrindeki hâkimiyeti 1792'ye kadar devam etmiştir. Cezayir'de 1830 yılındaki Fransız işgaline kadar devam eden 300 yıllık Osmanlı hâkimiyeti sırasında ülke, Beylerbeyi (1516-1587), Paşa (1587-1671) ve Dayılar (1671-1830) tarafindan yönetilmiştir" (Aslan \& Karakoç, 2014, s. 4).

14 Haziran 1830'da Fransızlar başkent Cezayir'i işgal etmiş ve şehir 5 Temmuz 1830'da Fransız egemenliğine girmiştir. İşgal, 20. yüzyılın ortalarına kadar devam etmiş, Kasım 1954'te ise Millî Kurtuluş Cephesi ve Ulusal Bağımsızlık Ordusu kurularak Cezayir'in bağımsızlık mücadelesi başlatılmıştır. Yaklaşık 8 yıllık mücadelenin ardından ülke bağımsızlığını kazanmış ve 5 Temmuz 1962'de Cezayir Demokratik Halk Cumhuriyeti ilan edilmiştir (Kocaeli Ticaret Odası, 2020, s. 5).

Cezayir ve Türkiye arasındaki ilişkilerin temeli, 16. yüzyıla dayanmaktadır. Barbaros Kardeşlerin 1516 yılında ülkeye gelmeleriyle başlayan Türkiye-Cezayir ilişkileri günümüze kadar varlığını sürdürmüştür. Cezayir halkının gerek Osmanlı gerekse Türkiye ve Türk milletine duyduğu sempati ve yakınlık bugün de geçerliliğini korumaktadır. Türkiye ve Cezayir arasında 2006 yılında "Dostluk ve İş Birliği Anlaşması" imzalanmış, 26-28 Şubat 2018 tarihlerinde düzenlenen "İ̧̧ Forumu"na iki ülkeden yaklaşık 700 iş adamı katılmıştır. Türkiye ve Cezayir eğitimden ticarete pek çok alanda iş birliği içerisinde çalışmalarını sürdürmekte, TİKA aracılığıyla Osmanlı mirası pek çok eser yenilenmekte, kültür ve eğitim alanlarındaki faaliyetlerin daha etkin şekilde yürütülebilmesi için ülkede Yunus Emre Enstitüsü açılmasına yönelik girişimler devam etmekte, mevcut Türkçe öğrenme talebinin karşılanması için Yunus Emre Enstitüsü ve Cezayir 2 Üniversitesi 
arasında imzalanan protokol çerçevesinde Türkiye'den Cezayir'e akademisyenler görevlendirilmektedir (Türkiye Cumhuriyeti Dışişleri Bakanlığı, 2020).

Ülkede Cezayir 2 Üniversitesi ve Emir Abdülkadir İslami Bilimler Üniversitesi bünyesinde faaliyet gösteren Türkoloji bölümleri ile farklı devlet üniversiteleri ve özel dil kurslarında Türkçe öğretimi faaliyetleri hâlen devam etmektedir.

\section{Amaç}

Yurt dişındaki Türkçe öğretim süreçlerinin değerlendirilmesi üzerine farklı çalışmalar gerçekleştirilmiştir (Bk. Dolunay, 2005; Temizyürek vd., 2016; Ustabulut \& Kara, 2016; Emek, 2017; Başar, 2018). Bu çalışmalar sayesinde gerek Türkçenin yurt dışında yabancı dil olarak öğretimi gerekse Türkoloji Bölümlerinin mevcut durumu hakkında değerlendirme ve planlamalar yapmak mümkün olacaktır.

$\mathrm{Bu}$ bağlamda araştırmada "Cezayir'de Türkçe öğretiminin güncel durumu nedir?” problem cümlesi altında aşağıdaki sorulara cevap aranmıştır:

1. Yunus Emre Enstitüsünün gerçekleştirdiği çalışmalar nelerdir?

2. Türkoloji Bölümlerinin güncel durumu nedir?

3. Türkçe kursları nelerdir?

4. Yürütülen projeler nelerdir?

5. Gerçekleştirilen bilimsel ve kültürel faaliyetler nelerdir?

Yöntem

Nitel araştırma modeli kullanılarak hazırlanan çalışma, Cezayir'deki Türkçenin güncel durumunu ortaya koymaya yönelik bir durum çalışmasıdır. Durum çalışması "nasıl ve niçin sorularını temel alan, araştırmacının kontrol edemediği bir olgu ya da olayı derinliğine incelemesine olanak veren araştırma yöntemidir" (Yıldırım \& Şimşek, 2018, s. 289).

\section{Etik Beyanı}

Araştırmada anket, mülakat, odak grup görüşmesi, gözlem, deney ve görüşme teknikleri kullanılmadığı için "Etik Kurul Onay Belgesi” alınmamıştır. Araştırma durum çalışması olarak tasarlanmış ve araştırmada Cezayir'de yabancı dil olarak Türkçe öğretiminin güncel durumu ele alınmıştır.

\section{Bulgular}

\section{Yunus Emre Enstitüsünün Gerçekleştirdiği Çalışmalara İlişkin Bulgular}

Yunus Emre Enstitüsü ile Cezayir 2 Üniversitesi arasında Kasım 2012 tarihinde imzalanan protokol çerçevesinde üniversite bünyesinde Yunus Emre Enstitüsü temsilciliğinin açılmasına karar verilmiş ve Enstitü ülkedeki faaliyetlerine başlamıştır. İlk olarak Cezayir 2 Üniversitesinde Türkoloji Bölümünün açılması amaçlanmış ve yürütülen çalışmalar sonucunda 2013 yılında Cezayir 2 Üniversitesinin Doğu ve Slav Dilleri Fakültesinde Türkoloji Bölümü kurulmuştur. Aynı yıl Konstantin şehrindeki Emir Abdülkadir İslami Bilimler Üniversitesinde de Türkoloji Bölümü açılmış ve her iki bölüm aynı yıl öğrenci kabul etmiştir. 
Enstitüsü Cezayir 2 Üniversitesinden sonra sirasıyla Oran Ahmed Ben Bella (2012), Emir Abdülkadir İslami Bilimler (2016), Medea Yahia Fares (2016) ve Mohamed Lamine Debaghin (2018) Üniversiteleri ile de iş birliği protokolleri imzalamış; bu üniversitelerde yürütülen Türkçe öğretimi çalışmalarına destek olmaya başlamıştır. Enstitü yürütülen Türkçe derslerinin desteklenmesi amaciyla Türkiye'den öğretim elemanı görevlendirmekte, ders kitapları ve ders materyalleri temin etmekte, Türkoloji öğrencilerinin çeşitli projelere katılmasını sağlamakta ve ülkede Türk kültürünü tanıtan etkinlikler düzenlemektedir.

Protokoller kapsamında Türkiye'den 2017-2018 eğitim-öğretim yılında 15, 2018-2019 eğitim-öğretim yılında 6 ve 2019-2020 eğitim-öğretim yılında 8 öğretim elemanı görevlendirilmiş; üniversitelerde okutulmak üzere başta Yedi İklim Türkçe Dil Öğretim Setleri olmak üzere pek çok Türkçe kaynak üniversitelere gönderilmiştir. Yunus Emre Enstitüsü, 2013 yılında T. C. Ziraat Bankasının destekleriyle yürütülen "100 Türkiye Kütüphanesi Projesi” kapsamında Cezayir 2 Üniversitesine bir kütüphane kurmuştur.

Enstitü her yıl düzenlediği Türkçe Yaz Okuluna 2016 yılından itibaren Cezayirli öğrencileri de davet etmeye başlamış, bugüne kadar 40 Cezayirli Türkoloji öğrencisi proje kapsamında Türkiye'yi görme ve Türk kültürünü yakından tanıma imkânı bulmuştur.

\section{Türkoloji Bölümlerinin Güncel Durumuna İlişkin Bulgular}

Cezayir'de Türkoloji Bölümleri 2013 yılında açılmıştır. İlk olarak başkentteki Cezayir 2 Üniversitesinde, daha sonra Konstantin şehrindeki Emir Abdülkadir İslami Bilimler Üniversitesinde Türkoloji Bölümü kurulmuştur. Türkoloji Bölümlerinde lisans düzeyindeki eğitim 3, yüksek lisans düzeyindeki eğitim ise 2 yıl sürmektedir.

Öğrenciler liseden mezun olma aşamasına geldiklerinde "Lise Bitirme Sınavı"na girmekte ve o sınavdan aldıkları puan ortalamalarına göre istedikleri üniversitelerin istedikleri bölümlerine yerleşebilmektedir. Bütünleme sınavlarına girenler veya son sınıfta kalanlar bu sınava girmek için ertesi yılı beklemektedir. Bölümlere yerleşme puanları kontenjan sayısına, mezun olunan lise türüne ve öğrencilerin bölümleri talep etme durumlarına göre değişmektedir. Somut şekilde örneklendirmek gerekirse "Yabancı Diller" bölümünden mezun bir öğrenci Türkoloji Bölümünü seçerse kontenjanlara göre tam puanın 20 puan olduğu sinavda 10 puan alması durumunda bile Türkoloji Bölümüne yerleşebilmektedir. "Sayısal” mezunu bir öğrencinin onu geçebilmesi için 20 puan üzerinden 14 puan alması gerekmektedir.

Öğrenciler programa kabul edildikten sonra direkt fakülteye geçmekte, Türkçe hazırlık sınıfında okumadan Türkçeyi bölüm dersleri ile birlikte öğrenmektedir. Emir Abdülkadir İslami Bilimler Üniversitesi Türkoloji Bölümünde lisans düzeyinde öğrencilerin aldıkları dersler şu şekildedir:

Tablo 1.

Emir Abdülkadir İslami Bilimler Üniversitesi Lisans Dersleri

\begin{tabular}{clc}
\hline Dönem & Dersler & Haftalık Ders Saati \\
\hline I. dönem & Ses Bilgisi & 1 \\
\hline
\end{tabular}




\begin{tabular}{|c|c|c|}
\hline \multirow[t]{9}{*}{ (14 Saat) } & Dilbilime Giriş & 1 \\
\hline & Dilbilgisi & 2 \\
\hline & Edebî Metinlere Giriş & 1 \\
\hline & Eski Türk Toplumu & 1 \\
\hline & Coğrafya & 1 \\
\hline & Metodoloji & 1 \\
\hline & Konuşma & 2 \\
\hline & Yazma & 3 \\
\hline & İngilizce & 1 \\
\hline \multirow{10}{*}{$\begin{array}{l}\text { II. dönem } \\
\text { (14 Saat) }\end{array}$} & Ses Bilgisi & 1 \\
\hline & Dilbilime Giriş & 1 \\
\hline & Dilbilgisi & 2 \\
\hline & Türk Edebiyatı & 1 \\
\hline & Dilin Kültürü ve Medeniyeti & 1 \\
\hline & Coğrafya & 1 \\
\hline & Metodoloji & 1 \\
\hline & Konuşma & 2 \\
\hline & Yazma & 3 \\
\hline & İngilizce & 1 \\
\hline \multirow{11}{*}{$\begin{array}{l}\text { III. dönem } \\
\text { (15 Saat) }\end{array}$} & Ses Bilgisi & 1 \\
\hline & Türk Edebiyat1 & 1 \\
\hline & Bilimsel Yazma & 1 \\
\hline & Tercümeye Giriş & 2 \\
\hline & Dilbilgisi & 2 \\
\hline & Osmanlı Medeniyeti & 1 \\
\hline & Bilgi ve İletişim Teknolojileri & 1 \\
\hline & Metodoloji & 1 \\
\hline & Konuşma & 2 \\
\hline & Yazma & 2 \\
\hline & İngilizce & 1 \\
\hline \multirow{11}{*}{$\begin{array}{l}\text { IV. dönem } \\
\text { (15 Saat) }\end{array}$} & Ses Bilgisi & 1 \\
\hline & Türk Edebiyatı & 1 \\
\hline & Dilbilim & 1 \\
\hline & Tercümeye Giriş & 2 \\
\hline & Dilbilgisi & 2 \\
\hline & Osmanlı Medeniyeti & 1 \\
\hline & İletişim Teknolojileri & 1 \\
\hline & Metodoloji & 1 \\
\hline & Konuşma & 2 \\
\hline & Yazma & 2 \\
\hline & İngilizce & 1 \\
\hline \multirow{11}{*}{$\begin{array}{l}\text { V. dönem } \\
\text { (14 Saat) }\end{array}$} & Tarihî Metinlerin İncelenmesi & 2 \\
\hline & Edebî Metinlerin İncelenmesi & 2 \\
\hline & Anında Çeviri & 1 \\
\hline & Osmanlı Hat Sanatı & 1 \\
\hline & Dilbilim & 2 \\
\hline & Didaktiğe Giriş & 1 \\
\hline & İletişim Bilimleri & 1 \\
\hline & Metodoloji & 1 \\
\hline & Konuşma & 1 \\
\hline & Yazma & 1 \\
\hline & İngilizce & 1 \\
\hline \multirow{5}{*}{$\begin{array}{l}\text { VI. dönem } \\
\text { (14 Saat) }\end{array}$} & Tarihî Metinlerin İncelenmesi & 2 \\
\hline & Edebî Metinlerin İncelenmesi & 2 \\
\hline & Anında Çeviri & 1 \\
\hline & Osmanlı Hat Sanat1 & 1 \\
\hline & Dilbilim & 2 \\
\hline
\end{tabular}




$\begin{array}{ll}\text { Didaktik } & 1 \\ \text { İletişim Bilimleri } & 1 \\ \text { Metodoloji } & 1 \\ \text { Konuşma } & 1 \\ \text { Yazma } & 1 \\ \text { İngilizce } & 1\end{array}$

Tablo 1 incelendiğinde öğrencilerin ilk iki ders döneminde onar, sonraki dönemlerde on birer ders aldıkları; mezun olmak için ise 64 dersi başarıyla tamamlamak zorunda oldukları görülmektedir. Yine öğrenciler ilk yıl haftada 14, ikinci yıl haftada 15 ve üçüncü yıl haftada 14 saat ders almaktadır. Programın tamamında 64 ders olmakla birlikte bazı derslerin birden fazla dönemde öğrencilere verildiği görülmektedir. Hangi dersin kaç dönem öğrencilere verildiğine ilişkin sayısal veriler şu şekildedir:

Tablo 2.

\section{Emir Abdülkadir Islami Bilimler Üniversitesi Dönemlere Göre Lisans Dersleri}

\begin{tabular}{lcc}
\hline Ders Adı & $\mathrm{n}$ & $\%$ \\
\hline Konuşma & 6 & 9,3 \\
Yazma & 6 & 9,3 \\
İngilizce & 6 & 9,3 \\
Metodoloji & 6 & 9,3 \\
Dilbilgisi & 4 & 6,2 \\
Ses Bilgisi & 4 & 6,2 \\
Osmanlı Hat Sanatı & 4 & 6,2 \\
Dilbilim & 3 & 4,6 \\
Türk Edebiyatı & 3 & 4,6 \\
Dil Bilime Giriş & 2 & 3,1 \\
Anında Çeviri & 2 & 3,1 \\
Coğrafya & 2 & 3,1 \\
Edebî Metinlerin İncelenmesi & 2 & 3,1 \\
Tarihî Metinlerin İncelenmesi & 2 & 3,1 \\
İletisisim Bilimleri & 2 & 3,1 \\
Tercümeye Giriş & 2 & 3,1 \\
Bilgi ve İletişim Teknolojileri & 1 & 1,5 \\
Bilimsel Yazma & 1 & 1,5 \\
Didaktiğe Giriş & 1 & 1,5 \\
Didaktik & 1 & 1,5 \\
Dilin Kültürü ve Medeniyeti & 1 & 1,5 \\
Edebî Metinlere Giriş & 1 & 1,5 \\
Eski Türk Toplumu & 1 & 1,5 \\
İletişim Teknolojileri & 1 & 1,5 \\
Toplam & 64 & 100 \\
\hline
\end{tabular}

Tabloya göre Türkoloji Bölümünden mezun olmak isteyen bir öğrencinin 24 farklı dersi tamamlaması gerektiği görülmektedir. Öğrenciler lisans eğitimleri boyunca Konuşma, Yazma, İngilizce ve Metodoloji dersleriyle 6; Dil Bilgisi, Ses Bilgisi ve Osmanlı Hat Sanatı dersleriyle 4; Dilbilim ve Türk Edebiyatı dersleriyle 3 kez karşılaşmaktadır. Öğrenciler Dil Bilime Giriş, Anında Çeviri, Coğrafya, Edebî Metinlerin İncelenmesi, Tarihî Metinlerin İncelenmesi, İletişim Bilimleri ve Tercümeye Giriş derslerini ikişer; Bilgi ve İletişim Teknolojileri, Bilimsel Yazma, Didaktiğe Giriş, Didaktik, Dilin Kültürü ve Medeniyeti, Edebî Metinlere Giriş, Eski Türk Toplumu ve İletişim Teknolojileri derslerini ise birer kez almaktadır. 
Diller için Avrupa Ortak Başvuru Metnine göre dil becerileri üretken ve algısal etkinlikler şeklinde ikiye ayrılmakta; üretken etkinlikler konuşma ve yazma, algısal etkinlikler ise dinleme ve okuma şeklinde verilmektedir (TELC, 2013). Türkoloji Bölümündeki dersler incelendiğinde programda tüm becerilere ait derslerin olmadığı yalnızca konuşma ve yazma derslerinin olduğu görülmektedir. Fakat derslerin uygulama aşamasına geçildiğinde öğreticilerin bu iki derste Yunus Emre Enstitüsünün "Yedi İklim Türkçe” dil öğretim setlerini kullandığı, öğretimin tüm becerilere yönelik gerçekleştirildiği, dil bilgisi kurallarının "Dil Bilgisi" derslerinde öğrencilere tekrar verildiği görülmüştür. Dil öğretim setleri hazırlanırken her bir seviyenin (A1, A2, B1, B2, C1 ve C2) 144 ders saatinde tamamlanmas1 planlanmıştır. Emir Abdülkadir İslami Bilimler Üniversitesinde konuşma ve yazma dersi toplamda birinci sınıfta haftada 5, ikinci sınıfta haftada 4 ve üçüncü sınıfta haftada 2 saat işlenmekte; her dönem 12 hafta ders yapılmaktadır. Bu programa göre öğrenciler lisans seviyesinden mezun olduklarında toplamda 264 saat yazma ve konuşma dersi almakta, öğreticiler bu sürede A1 ve A2 seviyelerini tamamlamaktadır.

2019-2020 eğitim öğretim yılına kadar Cezayir'de üniversiteler kendi imkânları doğrultusunda her sene yüksek lisansa kabul edecekleri öğrenciler için bir kontenjan belirlemekte, mezun öğrenciler yüksek lisansa başvurduklarında puan sıralamasına göre kontenjana dâhil olanlar yüksek lisansa başlamaktaydı. Türkoloji Bölümlerinde de süreç benzer şekilde yürütülmekte, öğrenciler programa kabul almak için herhangi bir sınava ya da mülakata girmemekteydi. Yüksek Eğitim Bakanlığı aldığı kararla 2020-2021 eğitim-öğretim yılından itibaren lisanstan mezun olan tüm öğrencilere yüksek lisansa başlama ve yüksek lisanstan mezun olan tüm öğrencilere doktora sınavına girme hakkı tanımıştır.

Yüksek lisansa kabul edilen öğrenciler ilk üç dönem ders almaktadır. Öğrencilerin yüksek lisansta aldıkları dersler şu şekildedir:

Tablo 3.

Emir Abdülkadir İslami Bilimler Üniversitesi Yüksek Lisans Dersleri

\begin{tabular}{clc}
\hline Dönemi & Dersler & Haftalık Ders Saati \\
\hline & Yeni Türk Edebiyatı & 2 \\
& Etik İlkelere Uygunluk & 1 \\
& Osmanlı Sanatları & 1 \\
& Bilimsel Yazma & 2 \\
I. dönem & Dilbilim & 3 \\
(17 Saat) & İletişim & 1 \\
& Metodoloji & 2 \\
& Konuşma & 3 \\
& Yazma & 1 \\
& Arapça & 1 \\
\hline & Yeni Türk Edebiyatı & 2 \\
& Araştırma Teknikleri & 2 \\
& Osmanlı Sanatları & 1 \\
& Etik İlkelere Uygunluk & 1 \\
& Dilbilim & 2 \\
& İletişim Teknikleri & 1 \\
& Bilimsel Yazma & 2 \\
& Konuşma & 3
\end{tabular}




\begin{tabular}{clc} 
& Yazma & 1 \\
& Arapça & 1 \\
\hline & Yeni Türk Edebiyatı & 2 \\
& Etik İlkelere Uygunluk & 1 \\
& Osmanlı Sanatları & 1 \\
& Bilimsel Yazma & 2 \\
III. dönem & Dilbilim & 3 \\
(17 Saat) & İletişim Bilimi Uygulamaları & 1 \\
& Metodoloji & 2 \\
& Konuşma & 3 \\
& Yazma & 1 \\
\hline IV. dönem & Arapça & 1 \\
\hline
\end{tabular}

Öğrenciler yüksek lisansın her bir döneminde onar ders almakta, üç dönem sonunda toplam otuz dersi başarmaları durumunda tez aşamasına geçmektedir. Üç dönemde öğrenciler 13 farklı ders almaktadır. Öğrenciler Arapça, Bilimsel Yazma, Dilbilim, Etik İlkelere Uygunluk, Konuşma, Osmanlı Sanatları, Yazma ve Yeni Türk Edebiyatı derslerini 3; Metodoloji dersini 2; Araştırma Teknikleri, İletişim, İletişim Bilimi Uygulamaları ve İletişim Teknikleri derslerini 1 kez almaktadır.

Yüksek lisans seviyesinde öğrenciler -tez yazım dönemi hariç- her dönemde toplam 4 saat konuşma ve yazma dersi almakta, dersler her dönem 12 hafta sürmektedir. Bu programa göre 3 dönem sonunda bir öğrenci 144 ders saati konuşma ve yazma dersi alarak yüksek lisanstan mezun olmaktadır. Yüksek lisans seviyesinde öğreticiler dil öğretimi için yine Yunus Emre Enstitüsünün hazırlamış olduğu "Yedi İklim Türkçe" setlerini kullanmakta, lisanstan A2 seviyesini bitirip gelen ögrrencilerle 3 dönemde B1 seviyesi tamamlanmaktadır.

Cezayir'deki Türkoloji Bölümlerinde doktora programları bulunmamakta, açılması için Bölüm Başkanlıkları gerekli çalışmaları yürütmektedir. Üniversitelerde herhangi bir alanda doktora programının açılması için aynı alanda "Prof. Dr." unvanına sahip iki öğretim üyesinin görev yapması gerekmektedir. Türkoloji Bölümlerinde görevli bu unvana sahip öğretim üyeleri bulunmadığ için Türkiye'den "Profesör" unvanına sahip en az iki akademisyenin sürece dâhil olması, Yabancı Diller Bölümünde görevli Cezayirli bir profesör üzerinden de doktora programlarının açılması planlanmaktadır.

Cezayir'deki Türkoloji Bölümlerine ilişkin sayısal veriler şu şekildedir:

Tablo 4.

Türkoloji Bölümlerine İlişkin Sayısal Veriler

\begin{tabular}{ccccccc}
\hline Üniversite & $\begin{array}{c}\text { Kuruluş } \\
\text { Yılı }\end{array}$ & $\begin{array}{c}\text { Derslik } \\
\text { Sayıs }\end{array}$ & $\begin{array}{c}\text { Öğrenci } \\
\text { Sayıs }\end{array}$ & $\begin{array}{c}\text { Mezun } \\
\text { Sayısı }\end{array}$ & $\begin{array}{c}\text { Öğretim } \\
\text { Elemanı } \\
\text { Sayıs1 }\end{array}$ & $\begin{array}{c}\text { Kütüphane } \\
\text { Olması } \\
\text { Durumu }\end{array}$ \\
\hline Cezayir 2 Üniversitesi & 2013 & 7 & 429 & 395 & 6 & Var \\
\hline $\begin{array}{c}\text { Emir Abdülkadir İslami } \\
\text { Bilimler Üniversitesi }\end{array}$ & 2013 & 4 & 124 & 106 & 4 & Var \\
\hline
\end{tabular}

Tablo incelendiğinde başkentteki Cezayir 2 Üniversitesinin öğrenci potansiyelinin daha yüksek olduğu, iki üniversitenin verileri dikkate alındığında ise 
Türkoloji Bölümleri adına ülkede önemli bir öğrenci sayısına ulaşıldığı görülmektedir.

Cezayir 2 Üniversitesinde 7 derslikte eğitim-öğretim sürdürülmektedir. $\mathrm{Bu}$ dersliklerden 3' ü TİKA tarafından yenilenmiş, 1 derslik ise kütüphaneye çevrilmiştir. $\mathrm{Bu}$ dersliklerde akıllı tahta, bilgisayar, projeksiyon ve ses sistemi mevcuttur. Fakat geri kalan 3 derslikte teknolojik araç-gereçlerden yoksun bir şekilde dersler yürütülmektedir. Bölümde hâlen 429 öğrenci bulunmaktadır. Bugüne kadar lisans veya yüksek lisans düzeyinden mezun olan 395 öğrenci vardır. Cezayir 2 Üniversitesindeki dersler 2019-2020 eğitim-öğretim yılında 6 öğretim elemanı ile tamamlanmıştır. Bu akademisyenlerin 4'ü Türkiye'den görevlendirilen, 2'si ise bölümde görev yapan Cezayirli öğretim elemanlarıdır.

Emir Abdülkadir İslami Bilimler Üniversitesi, Cezayir'in üçüncü büyük şehri olan Konstantin'de bulunmaktadır. Burada Türkoloji faaliyetleri Emir Abdülkadir Camisi binasında bulunan Edebiyat ve İslam Uygarlığı Fakültesi Türk Dili ve Kültürü Bölümünde gerçekleştirilmektedir. Bölümde 4 derslikte öğretim süreçleri yürütülmekte, dersliklerin yetersiz kaldığı durumlarda fakültedeki diğer bölümlerin derslikleri kullanılmaktadır. Mevcut dersliklerde akıllı tahta, bilgisayar, projeksiyon ve ses sistemi bulunmamaktadır. Bölümün lisans ve yüksek lisans düzeyinde 124 aktif öğrencisi olmakla birlikte bugüne kadar lisans veya yüksek lisans düzeyinden mezun olan öğrenci sayısı 106'dır. Türkoloji Bölümündeki dersler 2019-2020 eğitim-öğretim yılında 4 öğretim elemanı ile tamamlanmıştır. Bu akademisyenlerin 2'si Türkiye'den görevlendirilen, 2'si ise bölümde görev yapan Cezayirli öğretim elemanlarıdır. İngilizce, Arapça, Coğrafya gibi ortak derslerin yürütülmesinde fakültedeki diğer bölümlerin öğretim elemanlarından destek alınmaktadır. Fakültede tüm öğrencilerin kullanabildiği bir kütüphane ve bu kütüphanede Türkçe eserlerin yer aldığı bir bölüm vardır. Yine Türkoloji Bölümü bünyesinde de kendi öğrencilerinin yararlanabileceği bir kütüphanenin kurulması planlanmaktadır.

\section{Türkçe Kurslarına İliş̧kin Bulgular}

Cezayir'de Türkçe öğrenmeye talep oldukça fazladır. Bunda gerek Türkiye-Cezayir ilişkilerinin Osmanlı Dönemine kadar uzanması gerekse Türk dizilerinin ülkede çok meşhur olması etkili olmaktadır. Mevcut talebi karşılayabilmek için hem devlet kurumlarında hem de özel kuruluşlarda Türkçe kursları düzenlenmektedir.

Cezayir 2, Emir Abdülkadir İslami Bilimler, Medea Yahia Fares ve Mohamed Lamine Debaghin Setif 2 Üniversitelerinde Türkoloji Bölümlerinden mezun Cezayirliler Türkçe kursları düzenlemektedir. Kurslar özel okul mantığı ile düzenlenmekte, dersler öğreticilerin kendi hazırladıkları materyaller kullanılarak gerçekleştirilmektedir. Öğrenciler kursta haftada 4 saat Türkçe öğrenmekte, 8-9 kişilik gruplara sınıf açılmaktadır.

Cezayir'de Türkçe kursu veren özel kuruluşlardan bazıları ise şu şekildedir:

Tablo 5 .

Cezayir'deki Özel Dil Kurslart

\begin{tabular}{cc}
\hline Kurs Merkezi & Şehir \\
\hline ILM Center & Blida
\end{tabular}




Language Universe
Dz Speaking School
Massinissa School
Istanbul and Constantine Institute of Languages
Ecole Echourouk
Noramens Ecole de Formation
ICIL Skikda Institut de Langues

Language Universe

Dz Speaking School

Noramens Ecole de Formation
Cezayir

Cezayir

Konstantine

Konstantine

Konstantine

Konstantine

Skikda

Özel kurslarda da Türkoloji mezunu ya da Türkiye'de yükseköğrenim görmüş Cezayirliler Türkçe öğretmekte, kurumlar kendi hazırladıkları ders materyallerini Türkçe kurslarında kullanmaktadır. Düzenlenen Türkçe kurslarında öğreticiler dersleri genellikle Arapça üzerinden anlatmaktadır. Üst düzey kurslarda ise yalnızca konuşma derslerini Cezayir'de yaşayan Türk vatandaşları vermektedir. Bu kişilerin Türkçe öğretmeni olması hususunda kurumlar hassasiyet göstermemekte, herhangi bir alanda üniversite mezunu olan Türkleri ders verme konusunda yeterli görmektedir.

Kurumların gerek eğitim dili Arapça olan Türkçe kursları düzenlemeleri gerekse derslerde görev alan Türklerin uzmanlıklarının yabancılara Türkçe öğretimi olmaması dil öğretim süreçlerine olumsuz etki etmekte, kurslara devam eden Cezayirlilerin Türkçe öğrenmesi zorlaşmaktadır.

\section{Yürütülen Projelere İlişkin Bulgular}

Manisa Celal Bayar Üniversitesi ile Cezayir 2 Üniversitesi arasında imzalanan "Türkiye ve Cezayir Arasında Lisansüstü Eğitim Programları için Çift Danışmanlı Akademik İşbirliği Projesi" kapsamında Cezayirli öğrencilerin hem kendi üniversitelerinden hem de Manisa Celal Bayar Üniversitesinden bir danışman seçmeleri ve yüksek lisans tezlerini çift danışmanlı olarak tamamlamaları hedeflenmiştir. Proje kapsamında ayrıca öğrencilere burs desteği verilmiş; hem öğrenci hem de akademisyen hareketliliği sağlanarak bu sayede iki ülke toplumunun kaynaşması için zemin hazırlanmıştır.

Cezayir'deki Türkoloji Bölümlerinde hem Cezayirli hem de Türkiye'den görevlendirilen öğretim elemanları birlikte görev yapmaktadır. Türkiye'den akademisyenlerin görevlendirilmesi Cezayir'deki Türkoloji Bölümleri için kısa vadede hayati bir öneme sahiptir. Bununla birlikte Cezayirli Türkologların yetiştirilmesi ve Türkçe öğretim süreçlerine dâhil edilmesi uzun vadede önemli bir ihtiyaçtır. Türkiye Cumhuriyeti Cezayir Büyükelçiliği ve Yunus Emre Enstitüsü bu ihtiyacı gidermek için çeşitli çalışmalar gerçekleştirmekte, Türkoloji bölümleri ve öğrencileri desteklenerek öğrencilerin kendilerini Türkçede en iyi şekilde geliştirmeleri ve ülkelerinde Türk diline hizmet etmeleri hedeflenmektedir.

Yurtdışı Türkler ve Akraba Topluluklar Başkanlığı, Türkiye'de eğitim gören uluslararası öğrenciler sayesinde dünyaya ve kendi ülkelerine ait problemlere çözüm üretecek yeni nesiller yetiştirmek, firsat eşitliği sağlamak ve uluslar üstü bir bakış açısı geliştirmek amaçlarıyla 2012 yılında "Türkiye Bursları" projesini hayata geçirmiştir (Türkiye Bursları, 2020). Proje sayesinde dünyanın farklı ülkelerinden öğrencilere Türkiye'de yükseköğrenim görme imkânı verilmekte, başarılı ve maddi durumu iyi olmayan öğrencilerin Türkiye'de eğitimlerini tamamlayarak 
ülkelerindeki sorunlara çözüm üreten birer kültür elçisi olmaları hedeflenmektedir. Kaya (2014, s. 115) tarafindan hazırlanan araştırmaya göre 1 Mart-31 Temmuz 2013 tarihleri arasında Türkiye Bursları internet sitesini 10,908 Cezayirli ziyaret etmiştir. Aynı araştırmada British Council (2013'den aktaran Kaya, 2014, s. 41) verilerinden hareketle 2010 yılında 20,066 Cezayirlinin Fransa'ya eğitim almak üzere gittiği belirtilmiştir. Mevcut sayılar dikkate alındığında Cezayirlilerin Türkiye'de yükseköğrenim görmeye sıcak baktıkları görülmekte, bu durum Türkiye Bursları başvurularına da yansımaktadır. Proje kapsamında Türkiye'de eğitim görmek isteyen Türkoloji öğrencilerine de destek sağlanmaktadır.

\section{Gerçekleştirilen Bilimsel ve Kültürel Faaliyetlere İlişkin Bulgular}

Yunus Emre Enstitüsü ve Türk İşbirliği ve Kalkınma Ajansı Başkanlığının desteğiyle 13-14 Aralık 2017 tarihlerinde "Farklı Bakış Açıları ile Cezayir'deki Türk-Osmanlı Dönemi ve Mirası" sempozyumu başkent Cezayir'de gerçekleştirilmiştir. Türkiye ve Cezayir'den akademisyenlerin katıldığ 1 sempozyumda Türkiye-Cezayir ilişkilerinin yanı sıra Cezayir'deki Osmanlı eserleri hakkında bildiriler sunulmuş, TİKA tarafından Cezayir 2 Üniversitesine yaptırılan dil laboratuvarının açılışı gerçekleştirilmiştir (Anadolu Ajansı, 2017).

Yunus Emre Enstitüsü tarafından 2017 yılında beş farklı kıtada gerçekleştirilen “Anadolu'nun Renkleri Kadeş” gösterisi 9 Mayıs 2018 tarihinde yüzlerce kişinin katılımıyla Cezayir Opera Salonunda Cezayirlilerle buluşmuştur. Anadolu'da bulunan ve dünyanın ilk yazılı barış anlaşması olarak kabul edilen Kadeş’ten adını alan gösteride ebru gösterileri ve Anadolu'nun farklı yerlerinden yöresel danslar sergilenmiştir (Yunus Emre Enstitüsü, 2018)

Cezayir'in Laghouat şehrinde 15-17 Ekim 2019 tarihlerinde "1518-1918 Modern Çağda Deniz ve Çöl arasındaki Magrip Bölgesi'nde Osmanlı Politikası” sempozyumu gerçekleştirilmiş, programa ülkenin önemli üniversite ve araştırma kurumlarından temsilciler katılmıştır (Yunus Emre Enstitüsü, 2019).

28 Mayıs 2020 tarihinde Ortadoğu Araştırmaları Merkezi tarafından düzenlenen ve Cezayir'in Ankara Büyükelçisi Murad Adcabi ile Türkiye'nin Cezayir Büyükelçisi Mahinur Özdemir Göktaş'ın açılış konuşmalarını gerçekleştirdiği çevrim içi panelde "Türkiye-Cezayir İlişkilerinin Geleceği” konuşulmuş; Cezayir 2 Üniversitesindeki temsilcilikten bağımsız olarak Yunus Emre Enstitüsüne bağlı bir Türk Kültür Merkezinin ve Türkiye Maarif Vakfina bağlı bir okulun Cezayir'de açılmasının planlandığı dile getirilmiştir (Ortadoğu Araştırmaları Merkezi, 2020).

\section{Sonuç ve Öneriler}

Türkiye-Cezayir ilişkilerinin geçmişe dayanması, iki ülke arasındaki iş birliği çalışmalarının artarak devam etmesi, Türk dizilerinin Cezayir'de yoğun ilgi görmesi ülkede Türk diline ve kültürüne olan ilgiyi de artırmakta, her yaştan Cezayirli Türkçe öğrenmek istemektedir. Artan talebin karşılanabilmesi için ülkede farklı kurum ve kuruluşlar Türkçe kursları düzenlemekte, kursların sağlıklı bir şekilde yürütülebilmesi için süreci yönetecek öğretmenlerin yetiştirilmesi ihtiyacı doğmaktadır. 
Yunus Emre Enstitüsü ve Cezayir 2 Üniversitesi arasında imzalanan iş birliği protokolü ile 2013 yılında önce Cezayir 2 Üniversitesinde sonra Emir Abdülkadir İslami Bilimler Üniversitesinde Türkoloji Bölümü kurulmuştur. Bölümlerin gerçekleştirdiği faaliyetler, Cezayirli Türkologların ve Türkçe öğretmenlerinin yetiştirilmesi ve mevcut ihtiyacın giderilmesi açısından çok önemlidir. $\mathrm{Bu}$ bölümlerden mezun olan öğrenciler hem Cezayir'deki Türkçe öğretim süreçlerinde hem de ülkedeki Türk firmalarında görev almaktadır.

Cezayir'deki Türkoloji Bölümlerinde Türkçe hazırlık sınıfı bulunmamakta, öğrenciler 3 yılın sonunda lisans ve devam etmeleri hâlinde 2 yılın sonunda yüksek lisans mezunu olmaktadır. Liseden üniversiteye geçişte öğrencilerin girdikleri "Lise Bitirme Sınavı" dikkate alınmakta, Türkçeye olan talebin artmasıyla Türkoloji Bölümlerinin puanları da yükselmektedir.

Türkoloji Bölümlerinde Türkçe hazırlık sınıfının olmaması önemli bir sorun olarak dikkat çekmektedir. Nitekim öğrenciler, haftanın 5-7 ders saatinde Yedi İklim Türkçe öğretim setleri üzerinden Türkçe öğrenmeye çalışmakta, eş zamanlı olarak da bölüm derslerini almaktadır. Herhangi bir dilde yükseköğrenim görmek dili akademik anlamda kullanabilmeyi gerektirmektedir. Hiç Türkçe bilmeyen birinin Dilbilime Giriş, Eski Türk Toplumu, Metodoloji, Türk Edebiyatı, Dilin Kültürü ve Medeniyeti gibi dersleri başarmasını beklemek doğru değildir. Bu dersleri öğrencilerin ana dillerinde onlara vermek ise hem bölümün amacina hizmet etmeyecek hem de öğretim elemanı yetersizliğinden dolayı gerçekleşmeyecektir. Türkiye'den görevli öğretim elemanları Arapça bilmemekte, bu dersleri öğrencilere vermek istediklerinde onların kendilerini anlamadıklarını görmekte ve bunun üzerine genellikle yukarıda adı anılan dersler Türkçe öğretim derslerine dönüşmektedir.

Bölümlerin lisans düzeyindeki dersler incelendiğinde öğrencilerin mezun olabilmek için 6 ders döneminde 64 dersten başarılı olması gerektiği görülmektedir. Derslerin isimlerine ve içeriklerine bakıldığında ise 3 yıllık lisans düzeyinde 24 farklı ders tanımlaması olduğu, derslerin genellikle sonraki yıllarda da tekrar tekrar verildiği tespit edilmiştir. Bununla birlikte özellikle Türkiye'den görevli öğretim elemanlarının yürüttüğü derslerin tekrar tekrar öğrencilere tanımlanması durumunda bir önceki dönemde kalınan yerden ders takibinin sağlanmasının güç olduğu, her öğreticinin aynı konuları her dönem tekrar anlatma çabası içerisine girdiği görülmüştür. Özellikle öğrencilerin Türkçe konuşamadıkları bir ortamda Metodoloji, Osmanlı Hat Sanatı, Dilbilgisi, Ses Bilgisi, Dilbilim, Türk Edebiyatı gibi derslerin öğrencilere tekrar tekrar verilmesi doğru değildir. Yüksek lisans düzeyinde verilen dersler incelendiğinde de benzer bir durumun olduğu görülmektedir. Öğrenciler üç ders döneminin tamamında Arapça, Bilimsel Yazma, Dilbilim, Etik İlkelere Uygunluk, Osmanlı Sanatları ve Yeni Türk Edebiyatı dersleri almaktadır. Üstelik bu derslerin içerikleri incelendiğinde Bilimsel Yazma, Etik İlkelere Uygunluk ve Araştırma Teknikleri derslerinin birbirine benzer içeriklere sahip olduğu görülmüştür.

Türkoloji Bölümlerinin fiziksel imkânlarının kötü olduğu, çoğu sınıfta akıllı tahta, bilgisayar, projeksiyon ve ses sisteminin olmadığı görülmektedir. Türkoloji 
Bölümlerinin kendilerine ait sinıfları yetersiz kalmakta, sınıf bulunamadığı zamanlarda dersler aksamaktadır. Mevcut sinıfların aydınlatma, havalandırma, 1sınma vb. pek çok problemi bulunmaktadır. Başkentteki Cezayir 2 Üniversitesi için TİKA tarafından inşa edilen dil laboratuvarının açılışının üzerinden 3 yıl geçmesine rağmen Türkoloji Bölümünün yeni binaya taşınmadığı görülmektedir. Bölümlerdeki teknik eksiklikler ve sınıf yetersizlikleri öğretim süreçlerini olumsuz etkilemekte, öğretimin kalitesi ve başarısı düşmektedir.

Cezayir'deki Türkoloji Bölümlerinden mezun olan öğrenciler üniversitenin yüksek lisans kontenjanına girecek sıralamayı elde etmeleri durumunda -başarı durumlarına bakılmaksızın- yüksek lisansa başlama hakkı kazanmaktaydı. Yüksek Eğitim Bakanlığı aldığ1 kararla 2020-2021 eğitim öğretim yılından itibaren uygulanmak üzere kontenjan uygulamasını kaldırmış, lisanstan mezun olan tüm öğrencilere yüksek lisansa başlama ve hatta doktora sınavlarına katılabilme hakkı vermiştir. Alınan karar Cezayirlilerin yükseköğrenim düzeylerini artırmak adına önemlidir. Fakat bununla birlikte kararın Türkoloji Bölümleri özelinde alınmış doğru bir karar olmadığg düşünülmektedir. Türkçe konuşamadığı için Türkoloji Bölümünden lisans düzeyinde bile mezun olmayı hak etmeyen fakat uygulamadaki birtakım aksaklıklar nedeniyle derslerini tamamlayıp mezun olan öğrencilerin tekrar yüksek lisansa başlatılması ve bu kişilere doktora sınavına katılma hakkı tanınması yanlıştır. Nitekim herhangi bir Türkoloji Bölümünden mezun Türkoloğun Türkçe konuşamaması kabul edilebilecek bir durum değildir.

Cezayir'deki Türkoloji Bölümlerinin 2013 yılında kurulduğu dikkate alındığında yüksek lisans düzeyinde ilk mezunların 2017-2018 eğitim öğretim yılında verildiği ve sonrasında 2018-2019 ve 2019-2020 eğitim-öğretim yıllarında diğer uzman Türkologların mezun oldukları ortaya çıkmaktadır. Cezayir'deki Türkoloji Bölümlerinin akademik kadroları incelendiğinde Türkçe bilen yerel öğretim elemanlarının olmadığı, her iki üniversitenin Bölüm Başkanlığını yürüten akademisyenlerin Türkiye ve Türk dostu olduğu ama maalesef Türkçe bilmedikleri görülmektedir. Türkoloji Bölümlerinden mezun olan bu nesli öğrenim hayatları sonrasında doğru şekilde yönlendirmek, bu kişilerden Türkçe öğretim süreçlerinde yararlanmak ve başarılı olanları Türkoloji Bölümlerinde değerlendirmek çok önemlidir.

Üniversitelerin ve özel okulların bünyesinde düzenlenen Türkçe kurslarında bir düzen bulunmamaktadır. Buralarda kurumlara ve kişilere göre öğretim süreçleri farklı planlanmakta, kurslar beklenilen düzeyde Cezayirlilerin Türkçelerine katkı sağlamamaktadır. Başar'ın (2018, s. 16) Afganistan'daki Türkoloji programlarını değerlendirdiği araştırmasında da belirttiği gibi genel-geçer bir dil öğretim standardı oluşturabilmek için kısa, orta ve uzun vadeli eylem planları oluşturarak ülke özelinde dil öğretim politikasının belirlenmesi gerekmektedir. Belirli öğretim programları, ders kitapları ve materyaller temin edilerek kurs merkezlerine ulaştırılmalı; buralarda görev yapan öğreticiler için hizmet içi eğitim programları düzenlenmelidir. Nitekim fayda sağlamayan Türkçe kursları Cezayirlilerde Türkçeye karşı olumsuz bir tutum oluşmasına neden olabilmektedir. Cezayir'de Yunus Emre Enstitüsünün kurulmasının bu sorunları ortadan kaldıracağ düşünülmektedir. 
Cezayir'de hâlen temsilcilik düzeyinde çalışmalarını sürdüren Yunus Emre Enstitüsü dünyanın farklı ülkelerinde olduğu gibi Cezayir'de de Türk dilini ve kültürünü tanıtıcı çalışmalar gerçekleştirmekte, etkinlikler düzenlemekte, iş birliği protokolü imzaladığı üniversitelerde açılan Türkçe kurslarına ders kitabı ve materyal desteği sağlamaktadır.

Cezayir'de yabancı dil olarak Türkçe öğretiminin kalitesini artırmak ve mevcut sorunları çözmek için belirlenen öneriler şu şekildedir:

1. Yurt dışındaki Türkoloji bölümleri Türkçe Öğretmenliği bölümlerine çevrilmeli, bölümlerdeki Türk Dili ve Edebiyatı dersleri azaltılmalı yerine öğrencilerin Türkçelerini geliştirebilecekleri beceri dersleri eklenmelidir.

2. Bölümlere "Türkçe Hazırlık Sınıfı" getirilmelidir.

3. Bölümlerin önceliği Türk dilini ve kültürünü iyi şekilde öğrenip kendi ana dilinde anlatabilen değil, Türk dilini en iyi şekilde kullanabilen ve Türk kültürünü doğru şekilde anlatabilen bireyler yetiştirmek olmalıdır.

4. Mevcut müfredatlar incelenmeli ve tekrar eden dersler programdan kaldırılmalıdır.

5. Lisans düzeyinde başarısız olan öğrencilerin dersleri asgari puanlarla geçmelerine ve mezun olmalarına izin verilmemelidir.

6. Cezayir'deki Türkoloji Bölümlerinin sınıfları yeniden düzenlenmeli, teknik eksiklikler giderilmeli, Cezayir 2 Üniversitesi Türkoloji bölümü bir an önce 2017 yılında açılışı gerçekleştirilen dil laboratuvarının olduğu binalara taşınmalıdır.

7. Lisans mezunu öğrencilerin yüksek lisansa alım süreçlerinde yazılı ve sözlü sınavlar gerçekleştirilmeli, başarısız olan öğrenciler programa kabul edilmemelidir.

8. Türkoloji öğrencilerine öğrenim hayatları sırasında hedef dilde pratik yapabilecekleri öğrenme ortamları sunulmalı, öğrencilerin belli projelerle Türkiye'de kısa süreli de olsa eğitim almaları sağlanmalıdır.

9. Türkoloji mezunlarına öncelikle Cezayir'deki üniversitelerde, sonrasında Türk firmalarında iş imkânları sağlanmalıdır.

10. Türkiye Bursları programında Türkoloji öğrencilerine öncelik tanınmalı, bu öğrencilerin yükseköğrenimlerini Türkiye'de tamamlamalarına önem verilmelidir.

11. Türkiye'deki yükseköğrenim kurumları ile Cezayir'dekiler arasında iş birliği protokolleri imzalanmalı, gerçekleştirilecek projelerle öğrenci ve öğretim elemanı hareketliliği sağlanmalıdır.

12. Türkiye'den uzmanların katılımıyla sempozyum, konferans vb. akademik etkinlikler düzenlenmeli, Türkoloji Bölümleri daha aktif hâle getirilmelidir.

13. Ülkede Yunus Emre Enstitüsü ve Türkiye Maarif Vakfına bağlı merkezler ile okullar açılmalıdır.

14. Türk kültürünü tanıtan sinema, tiyatro ve dans gösterimleri; geleneksel kıyafetlerin sergilendiği defileler; Türk mutfağını, yemeklerini, tatlılarını tanıtan atölyeler düzenlenmelidir. 


\section{Çıkar Çatışması ve Etik Bildirimi}

Bu makale kuramsal bir makaledir. Katılımcıların yer aldığı herhangi bir uygulama ve deney çalışması içermemektedir. Bu nedenle etik kurul onayı için başvuruda bulunulmamıştır. Makalede bilimsel, etik ve alıntı kurallarına uyulmuş; bilimsel gerçekler üzerinde herhangi bir çarpıtma yapılmamıştır. Etik ihlal sorumluluğunun yazara ait olduğu ve bu makalenin daha önce yayınlanmamış ve paylaşılmamış olduğu sorumlu yazar tarafından taahhüt edilmiştir.

\section{Kaynakça}

Anadolu Ajans1 (2017). Cezayir'de “Osmanlı Mirası" sempozyumu başladl. https://www.aa.com.tr/tr/dunya/cezayir-de-osmanli-mirasi-sempozyumu-basladi/1003772 adresinden 20 Aralık 2020 tarihinde alındı.

Aslan, H., \& Karakoç, E. (2014). Cezayir ülke raporu. Cezayir: T.C. Cezayir Büyükelçiliği Ticaret Müşavirliği. https://www.tavsanlitso.org.tr/ adresinden 27 Aralık 2020 tarihinde alındi.

Başar, U. (2018). Afganistan'da yabancı dil olarak Türkçe öğretimi üzerine güncel bir değerlendirme. Aydın TÖMER Dil Dergisi, 3(1), 1-20.

British Council (2013). Country briefs. www.britishcouncil.org adresinden 15 Ocak 2014 tarihinde alındı.

Dolunay, S. K. (2005, 28-30 Eylül). Türkiye ve dünyadaki Türkçe öğretim merkezleri ve Türkoloji bölümleri üzerine bir değerlendirme [Sözlü Bildiri]. XIV. Ulusal Eğitim Bilimleri Kongresi, Denizli, Türkiye.

Emek, M. (2017). Cezayir 2 Üniversitesi Türkoloji bölümü temel düzey (A1-A2) Türkçe ögretim programının diller için Avrupa ortak öneriler çerçevesi bağlamında Stuflebeam'in çevre girdi süreç ürün modeliyle değerlendirilmesi (Doktora tezi). Atatürk Üniversitesi.

Erinç, S. (1993). Cezayir. Türkiye Diyanet Vakfi İslam Ansiklopedisi. (Cilt. 7, ss. 483-485). İstanbul: Türkiye Diyanet Vakfı İslam Araştırmaları Merkezi.

Kahraman, K. (1993). Osmanlı dönemi. Türkiye Diyanet Vakfi Íslam Ansiklopedisi. (Cilt. 7, ss. 486-489). İstanbul: Türkiye Diyanet Vakfi İslam Araştırmaları Merkezi.

Kaya, M. F. (2014). Uluslararası öğrenci hareketliliğinde lider 6 dünya ülkesinin yüksekögrretim tanttım uygulamalart ve Türkiye Bursları tanttım stratejisi için bir model önerisi. (Uzmanlık tezi). T.C. Başbakanlık Yurtdışı Türkler ve Akraba Topluluklar Başkanlığı.

Kocaeli Ticaret Odas1 (2020). Cezayir ülke raporu. http://koto.org.tr/images/upload/3c6cb441d9bcc003c8379ad634a99528.pdf adresinden 10 Aralık 2020 tarihinde alındı.

Ortadoğu Araştırmaları Merkezi (2020). Türkiye-Cezayir ilişkilerinin geleceği. https://orsam.org.tr/tr/turkiye-cezayir-iliskilerinin-gelecegi-2/ adresinden 7 Aralık 2020 tarihinde alındı.

TELC (2013). Diller için Avrupa ortak öneriler çerçevesi-öğrenim, ögretim ve değerlendirme. Telc GmbH.

Temizyürek, F., Barın, E., \& Ustabulut, M. Y. (2016). Afganistan'ın dil politikası ve Afganistan'da Türkçe eğitimi tarihi. Türkbilig, (32), 155-168. 
Türkiye Bursları (2020). Türkiye Bursları projesi. https://turkiyeburslari.gov.tr/tr adresinden 7 Aralık 2020 tarihinde alınd.

Türkiye Cumhuriyeti Dışişleri Bakanlığı (2020). Türkiye - Cezayir siyasi ilişkileri. http://www.mfa.gov.tr/turkiye-cezayir-siyasi-iliskileri.tr.mfa adresinden 1 Aralık 2020 tarihinde alındi.

Ustabulut, M. Y., \& Kara, K. (2016). Romanya'da Türk dili tarihi ve Dobruca'daki (Köstence) Türkoloji eğitimi. Aydın TÖMER Dil Dergisi, 1(2), 1-16.

Yıldırım, A., \& Şimşek, H. (2018). Sosyal bilimlerde nitel araştırma yöntemleri (11. Baskı). Seçkin Yayıncılık.

Yunus Emre Enstitüsü (2018). Anadolu'nun renkleri Kadesh kardeş ülke Cezayir'de. https://www.yee.org.tr/tr/haber/anadolunun-renkleri-kadesh-kardes-ulke-cezayirde adresinden 14 Aralık 2020 tarihinde alındı.

Yunus Emre Enstitüsü (2019). Mağrip bölgesinde Osmanlı politikası Cezayir'de konuşuldu. https://www.yee.org.tr/tr/haber/magrip-bolgesinde-osmanli-politikasi-cezayirdekonusuldu adresinden 10 Aralık 2020 tarihinde alındı.

\section{Extended Abstract}

The basis of relations between Algeria and Turkey, are based on the 16th century and the sympathy and closeness of the Algerian people has for the Turkish nation are still valid today. Developing relations and Turkish TV series, which are closely followed in Algeria, increase the interest in learning Turkish in Algeria, and various institutions and organizations in the country carry out various activities to meet this demand.

In the study, which was prepared using the case study, one of the qualitative research designs, it was aimed to reveal the general situation and evaluate the teaching of Turkish as a foreign language in Algeria

The activities carried out by Turcology departments in Algeria are very important in terms of training Algerian Turcologists and Turkish teachers and meeting their demands of learning Turkish. The students who graduate from these departments take part in Turkish teaching processes in Algeria as well as in Turkish companies in the country.

The absence of a Turkish preparatory class in Turcology Departments draws attention as an important problem. As a matter of fact, the students try to learn Turkish with the Yedi İklim Turkish teaching sets in 5-7 lessons a week and simultaneously take the department courses. Studying at higher education in any language requires being able to use the language academically. The students who do not know any Turkish fail in the courses such as Introduction to Linguistics, Ancient Turkish Society, Methodology, Turkish Literature, Culture and Civilization of Language.

When the undergraduate courses of the departments are examined, it is seen that the students must pass 64 courses in 6 course terms in order to graduate, From the names and contents of the courses, it was found out that there were 24 different course descriptions at the 3-year undergraduate level and the courses were generally given again and again in the following years. When the courses by the academic staff coming from Turkey are assigned to the students again and again, it is seen that 
it is difficult to follow the follow-up courses from the previous part and for every lecturer to explain the same topics every semester. Especially in an environment where students cannot speak Turkish, it is not correct to give the courses such as Methodology, Ottoman Calligraphy, Grammar, Phonology, Linguistics and Turkish Literature to the students over and over.

It is observed that the physical facilities of Turcology Departments are bad and most classrooms do not have smart boards, computers, projectors and sound systems. The classes of Turcology Departments are insufficient, and some lessons can't be done when there is no class. There are also problems such as lighting, ventilation, heating, etc.

The students who have graduated from Turcology Departments in Algeria have gained the right to start a master's degree without being subjected to any exams since 2020-2021 academic year. It is wrong for the students who do not deserve to graduate from the Department of Turcology even at the undergraduate level because they cannot speak Turkish but who have completed their courses and graduated due to some problems in practice to start the master's degree again and to have the right to take the doctoral exam. This will decrease the success in Turcology Departments.

It is necessary to direct the graduates of Turcology departments properly, to employ them in Turkish companies, to benefit from them in Turkish teaching processes and to employ the successful ones in Turcology Departments.

The recommendations to increase the quality of teaching Turkish as a foreign language and to solve the current problems in Algeria are as follows.

1. Turcology departments abroad should be converted to Turkish Language Teaching departments, and the number of the Turkish Language and Literature courses in the departments should be reduced. Instead, the skill courses should be added to enable students to improve their Turkish.

2. The departments should have "Turkish Preparatory Classes".

3. The priority of the departments should be to train individuals who can use the Turkish language in the best way and can explain Turkish culture correctly instead of those who can learn Turkish language and culture well and express them in their native language.

4. Existing curricula should be reviewed and repeating courses should be removed from the program

5. The students who fail at the undergraduate level should not be allowed to pass the courses with minimum scores and graduate from the program.

6. The classes of Turcology Departments in Algeria should be rearranged, technical deficiencies should be eliminated, and Turcology Department of Algeria University should be moved to the buildings where the language laboratory was opened in 2017 as soon as possible.

7. Written and oral exams should be held in the master degree admission process of the undergraduate students and the students who fail should not be admitted to the program.

8. The students should be presented learning environments in which they can practice in the target language during their academic lives and be given the opportunity to study thanks to the specific short-term projects in Turkey. 
9. Turcology graduates should be provided with job opportunities firstly in the universities in Algeria and then in the Turkish companies

10. Turcology students should be given priority in Turkey Scholarships Program and it is important for these students to complete their higher education in Turkey.

11. The cooperation protocols should be signed between the higher education institutions in Turkey and those in Algeria and the student and staff mobility must be realized between them.

12. Academic events such as symposium and conferences should be organized with the participation of the experts from Turkey and Turcology Departments should be made more active.

13. Centers and schools affiliated to Yunus Emre Institute and Turkey Maarif Foundation should be opened.

14. Cinema, theater and dance performances promoting Turkish culture; fashion shows displaying traditional clothing; workshops promoting Turkish cuisine, dishes and desserts should be organized. 